\title{
Study on Continuing Education Mode of Judicial Police Colleges and Universities from Perspective of Learning Society
}

\author{
Jing Feng, Jiantong Ren, Liya Su \\ The Central Institute for Correctional Police, Baoding, Hebei, 071000, China
}

Keywords: Learning society, Continuing education, Judicial police colleges and universities

\begin{abstract}
To guarantee orderly implementation of modern judicial work, it is required to strengthen the education for important forces maintaining judicial work, i.e. judicial police officers. Therefore, it is inevitable to strengthen the study on continuing education mode of judicial police colleges and universities and make judicial police officers meet the demand of modern judicial work. This paper describes connotations of learning society and continuing education, analyzes their relation and finally discusses countermeasures for improving teaching quality of continuing education in judicial police colleges and universities from the perspective of learning society.
\end{abstract}

\section{Introduction}

In the current era, the development of knowledge-based economy and the construction of learning society become a development trend of the era. The concept of lifelong learning and learning for all enjoys popular support. More and more people have developed a learning attitude of "lifelong learning” . Due importance should be attached to continuing education which is an important carrier of lifelong learning and learning for all. For judicial police colleges and universities, it is very necessary to attach importance to continuing education work, improve the teaching quality of continuing education by various means and cultivate talents meeting demands of era development and social progress.

Therefore, judicial police colleges and universities should increase practical teaching, choose appropriate teaching contents according to market demand, improve teachers' theoretical level and professional skills, create high-quality “double-type” teacher group, combine theory and practice closely and improve the teaching quality of continuing education.

\section{Connotations of learning society}

American scholar Robert Hutchings first put forward the concept of learning society in 1960s. Then, UNESCO started to advocate the establishment of learning society in various countries and regions in 1970s.Since then, many countries have established learning society successively.

Learning society refers to the society of lifelong learning and learning for all realized with scientific and rational means through the establishment of corresponding system ${ }^{[1]}$.Learning for all and lifelong learning are core connotations of learning society. Its feature is the formation of a positive learning atmosphere in the society with lifelong learning and learning for all.

Demands of era development and social progress have promoted the emergence of learning society. In the current era, science and technology are developing rapidly and the amount of knowledge and information is increasing sharply. It can even be said that we have stepped into the era of "information explosion". This causes constant increase of knowledge innovation speed and shorter update cycle. Therefore, higher requirements are put forward for all human beings. Strengthening learning becomes an urgent task of each person, organization and the whole society. Under such serious situation, people in the whole society can improve their level and cope with various possible challenges easily only by establishing the concept of “live and learn” , adhering to the attitude of lifelong learning and studying constantly.

Learning society has more comprehensively, lasting and stronger requirements for the study of human beings. It cannot be achieved through efforts of one person or organization independently. 
Instead, resources and forces in the whole society should be integrated organically and learning society should be established gradually through the establishment of learning family, organization, community and city according to demands of practical development.

\section{Connotations of continuing education}

Continuing education is an educational form developed after human society reaches certain development degree as well as a vital constituent part under modern educational system ${ }^{[2]}$.With the rapid development of science and technology in the current era, knowledge economy has gradually developed. Under such environment, people start to pay attention to continuing education and attach more importance to it. Functions of continuing education become prominent under the positive construction of learning society with lifelong learning and learning for all, which not only promote the construction and development of learning society effectively, but also promote the development and progress of the whole society.

Continuing education refers to various educational activities for on-the-job personnel having completed or separated from formal education, having adult responsibilities and joining in work. Professional technicians can add and update their concept and knowledge, master new skills, improve their professional quality and ability and achieve the development at higher levels by receiving continuing education. Continuing education includes adult academic education and non-academic education. Its main teaching contents include new concept, knowledge, methods, skills and information imparted to educatees.

After completing formal education in the school, all members of the whole society, especially adults, can pursue advanced studies, learn new knowledge, master new skills and achieve further development through continuing education. From this perspective, continuing education is an important way for people to implement the concept of lifelong learning, which can cultivate the good habit of lifelong learning effectively. To meet current demands of world economic development and social progress, the effective implementation of continuing education work should meet stricter standards. Therefore, there are more deeper researches on continuing education and the practical link of continuing education is developed constantly. So far, China has clear preliminary understandings of the role and status of continuing education in the society and economy and its methods. The practical experience in continuing education becomes richer and more and more people in the society start to accept the concept of lifelong learning and make constant efforts for it.

Continuing education is different from formal education in schools. It has a relatively special educational form. Its main teaching contents include the supplement and updating of knowledge that has been mastered by professional technicians so as to allow them to master new and advanced knowledge and professional skills, improve their professional quality and skills, expand their horizon, optimize their knowledge structure, give full play to their innovation ability and meet vocational demands and requirements of scientific and technological development and social progress. In the current era of knowledge economy, the development of human resources relies on continuing education. Continuing education has vital significance and functions in this aspect. Continuing education can fully exploit potential abilities of talents, cultivate their comprehensive quality, improve the overall quality of professional talent team comprehensively, establish a professional technician team with strong technology and high comprehensive quality and promote the development of science and technology and social progress effectively.

\section{Relation between learning society and continuing education in judicial police colleges and universities}

Core connotations of learning society are lifelong learning and learning for all. Continuing education work implemented in judicial police colleges and universities is an additional education implemented for on-the-job judicial police officers having completed or separated from formal education in schools. Such education is a specific manifestation of lifelong learning of judicial police officers. The relation between learning society and continuing education can be analyzed in the 
following aspects: first, continuing education implements the concept of lifelong learning. The form and teaching contents of continuing education are the premise and foundation of the formation and development of lifelong learning concept. Moreover, continuing education is also a specific manifestation of lifelong learning concept in practice. The specific manifestation of formation mode of learning for all is continuing education. Continuing education is an equal educational activity for all people. Learning society advocates learning for all and regards all people as educational objects. Finally, an important way for realizing comprehensive development of people is continuing education. Continuing education can not only improve the educational degree of educatees, but also train their professional ability. Through continuing education, educatees can further improve their professional skills, complete the work better, constantly improve their knowledge and skills with constant learning and finally achieve comprehensive development.

\section{Countermeasures for strengthening continuing education in judicial police colleges and universities from the perspective of learning society}

Add practical teaching. The work of judicial police officers is strongly practical. They might encounter many emergency situations in the work process. This requires them to have a good ability of adaption to circumstances. Therefore, it is essential to add effective practical teaching for them. Judicial police colleges and universities should attach importance to practical teaching, allocate appropriate proportions of theoretical and practical teaching ${ }^{[3]}$, guarantee the effectiveness of practical teaching and meanwhile exert characteristics of judicial police education when implementing continuing education for students. First, judicial police colleges and universities should change the concept and not only pay attention to theoretical knowledge instruction for students but also guarantee their mastery of professional skills and treat practical and theoretical teaching equally. Practical teaching should not be attached to theoretical teaching; instead, it should be independent. It is required to establish relatively independent teaching objectives and system according to practical teaching and improve software and hardware facilities required for practical teaching so as to cross theory and practice and allow students to put on their thinking cap and start work. Second, judicial police colleges and universities need to increase class hours of practical teaching, keep the proportion of theoretical and practical teaching about 3:2 and adjust the proportion of some professional education contents with strong skills into 1:1 and even greater. Then, strongly pragmatic textbooks for practical teaching should be developed. According to the current situation, judicial police education lacks strongly pragmatic textbooks for practical teaching, which is obviously adverse to the improvement of practical ability of students. Therefore, judicial police colleges and universities should attach importance to the development of textbooks for practical teaching, make practical projects supported by appropriate textbooks and help students understand and master practical teaching contents. Finally, to guarantee the effectiveness of practical teaching, it is necessary to establish efficient practical teaching management system so as to implement practical teaching activities smoothly and achieve expected teaching objectives. Judicial police colleges and universities should establish a complete practical teaching management system, specify responsibilities of each department, designate high-level professional talents for the management of practical teaching, strengthen process management and form efficient management mechanism with advance preparation, examination in process and post-evaluation ${ }^{[4]}$.

Advance with the times and meet market demands. Continuing education of judicial police colleges and universities should establish the concept of advancing with the times, get rid of the stale and bring forth the fresh and cultivate judicial police talents meeting market demands. Teaching contents of continuing education in judicial police colleges and universities cannot remain unchanged. Some obsolete contents lagging behind era development cannot be used as main teaching contents, which will cause the failure of judicial police officers cultivated to meet demands of practical work. Therefore, judicial police colleges and universities should consider market factors comprehensively when selecting teaching contents and establishing teaching objectives. A market survey group can be established or special persons can be assigned to conduct market survey and get relevant information of front-line work and actual demands of the current industry. It is required to choose teaching 
contents according with the reality according to the result of market survey and delete teaching contents that cannot meet market demands in time. In the teaching process, judicial police colleges and universities should track the change of the society dynamically so as to adjust teaching objectives and contents in time in the case of social change, allow judicial police talents cultivated to meet requirements of front-line work and improve the teaching quality of continuing education in judicial police colleges and universities.

Build “double-type” teacher group. Main teaching contents of continuing education include helping educatees master new and advanced concepts, knowledge and professional skills. This requires teachers responsible for front-line teaching to have complete and rich knowledge as well as high professional skill level. Work theory and practice of judicial police officers are indispensable. During continuing education, effective teaching in both aspects should be guaranteed. Therefore, judicial police colleges and universities should cultivate teachers' professional skills and build a "double-type" teacher group while enriching theoretical knowledge of teachers. They should cultivate and improve professional skill level of teachers by various means and through various channels. Teachers should be organized periodically or aperiodically to enter the front line of work of judicial police officers and observe their actual work process and specific work situation carefully so as to master the latest information. Judicial police colleges and universities can cooperate with relevant organizations and arrange teachers for taking a temporary post for practice so as to cultivate their knowledge application ability and practical skills comprehensively. The annual practice time of teachers should be no less than one month. Meanwhile, they should organize teachers for training periodically so that they can master advanced information and latest technologies in the industry. In addition, judicial police colleges and universities should optimize the existing teacher management system, make teacher recruitment mechanism strict, introduce high-quality and high-level teachers who should not only be able to implement theoretical teaching effectively but also be able to implement practical teaching efficiently and combine theory and practice, encourage teachers to participate in teaching research activities positively and actively so as to improve their business level and professional skills, and establish rational reward and punishment mechanism and occupational promotion mechanism so as to allow teachers to know requirements and standards for promotion and stimulate their initiative. Judicial police colleges and universities can establish a high-quality "double-type" teacher group through such measures so as to improve the teaching quality of continuing education and cultivate judicial police talents meeting requirements of era development and social progress.

\section{Conclusion}

In conclusion, under the background of construction of learning society, judicial police colleges and universities should attach more importance to continuing education work, increase the proportion of practical teaching, cater for market demands, establish “double-type” teacher group and closely combine theory and practice so as to provide high-quality education services and promote the development of learning society with learning for all and lifelong learning.

\section{Acknowledgments}

This paper is a project of Education Department in 2014. Project name: Study on Continuing Education Mode of Judicial Police Colleges and Universities from Perspective of Learning Society; Project No. SZ141203.

\section{References}

[1] Xia Yu, Liu Jun. Learning Society: from Educational Concept to Development Mode. Jiangxi Social Science, 2010,(6):218-221. 
[2] Zhang Zhongbing. Development Dilemma of Higher Vocational Continuing Education and Countermeasures. Journal of Sichuan Technical Institute, 2012,22(4):97-100.

[3] Li Xiuhua. Implement Continuing Education Well and Strengthen Construction of Higher Vocational Teacher Group. Continuing Education, 2010,24(8):19-21.

[4] Hou Wei. Problems Faced by Development of Judicial Police Colleges and Universities and Countermeasures. Vocational Education (Last Ten-day Period of the Month), 2013,(1):4-6.

[5] Li Yu'e. Discussions on Cultivation of Applied Innovative Talents in Judicial Police Colleges and Universities. Journal of An'hui Police Vocational College, 2012,11(2):85-88. 